\title{
HYPOTHYROID MYOPATHY OR RHABDOMYOLYSIS
}

Sir,

The article "Hypothyroidism-associated rhabdomyolysis" was interesting. ${ }^{[1]}$ The clinical description of the patient fits in with the diagnosis of hypothyroid myopathy. The serum creatinine value is practically normal $(1.6 \mathrm{mg} \%)$, and the fact that the patient has a normal blood urea and a normal urine output indicates that the renal function is virtually normal. Rhabdomyolysis is a more severe illness which presents acutely with features of myalgias, hyperkalemia, renal dysfunction, metabolic acidosis and features of disseminated intravascular coagulation, apart from elevated creatinine kinase levels. Also, the serum creatinine kinase levels are about 5 times the normal, which is possible even in hypothyroid myopathy. Even levels up to 9000 have been reported. ${ }^{[2]}$ All in all, the case appears to be more of a hypothyroid myopathy rather than a rhabdomyolysis.

The authors also mention that the patient has borderline first-degree heart block on EKG. In the setting of rhabdomyolysis, this should alert the clinician about the possibility of hyperkalemia secondary to muscle damage. The authors fail to mention the serum $\mathrm{K}+$ levels and also whether the abnormality improved with treatment.

VISHAL SHARMA, ALKA SHARMA, SOURABH AGGARWAL

Department of Medicine, University College of Medical Sciences and GTB Hospital, Delhi, India

Correspondence: Vishal Sharma, 19 Gobind Nagar Chheharta, Amritsar - 143 105, India. 


\section{REFERENCES}

1. Chowta MN, Chowta NK. Hypothyroidismassociated rhabdomyolysis. Indian J Med Sci 2008;62:496-7.
2. Finsterer J, Stöllberger C, Grossegger C, Kroiss A. Hypothyroid myopathy with unusually high serum creatine kinase values. Horm Res 1999;52:205-8.

DOI: $10.4103 / 0019-5359.49248$

\section{Author Help: Reference checking facility}

The manuscript system (w ww.journalonw eb.com) allows the authors to check and verify the accuracy and style of references. The tool checks the references with PubM ed as per a predefined style. Authors are encouraged to use this facility, before submitting articles to the journal.

- The style as well as bibliographic elements should be $100 \%$ accurate, to help get the references verified from the system. Even a single spelling error or addition of issue number/month of publication will lead to an error when verifying the reference.

- $\quad$ Example of a correct style

Sheahan P, O'leary G, Lee G, Fitzgibbon J . Cystic cervical metastases: Incidence and diagnosis using fine needle aspiration biopsy. Otolaryngol Head Neck Surg 2002;127:294-8.

- Only the references from journals indexed in PubM ed will be checked.

- $\quad$ Enter each reference in new line, without a serial number.

- Add up to a maximum of 15 references at a time.

- If the reference is correct for its bibliographic elements and punctuations, it will be shown as CORRECT and a link to the correct article in PubM ed will be given.

- If any of the bibliographic elements are missing, incorrect or extra (such as issue number), it will be shown as INCORRECT and link to possible articles in PubM ed will be given. 